\title{
Pengaruh Pendapatan Asli Daerah (PAD), Dana Alokasi Umum (DAU) dan Dana Alokasi Khusus (DAK) Terhadap Alokasi Belanja Daerah Pada Kabupaten/Kota di Jawa Timur
}

Diah Ekaningtias ${ }^{1}$

${ }^{1}$ STIE Perbanas Surabaya, Jalan Nginden Semolo 34-36 Surabaya 60118. Indonesia.

I N F O A R T I K E L

JEL Classification:

H83

M12

\section{Keywords:}

local revenue, general allocation fund, special allocation fund, budget allocation

\section{$A B S A R A C T$}

This study aims to determine whether there is influence of local revenue (PAD), the general allocation fund (DAU) and special allocation fund (DAK) for budget allocations in the areas measured by indirect expenditures and direct spending. The sample of population in this study was 38 district in East Java in the year 2010 to 2012. This study uses secondary data in the form of the Budget Statement of Revenue and Expenditure (APBD) District. The sampling method using a census method by taking the entire population. Research tool used is multiple linear regression. The results of this study indicate that the PAD, DAU, $D A K$ has a positive and significant impact on indirect expenditure, if seen further, the level of dependence of indirect expenditure is more dominant compared to the DAU and DAK whereas PAD, DAU has a positive and significant impact against direct spending. DAK perpengaruh positive and significant impact on direct spending, the level of dependence of direct expenditure is more dominant against PAD compared with DAU and $D A K$.

\section{A B S T R A K}

Penelitian ini bertujuan untuk mengetahui apakah ada pengaruh pendapatan asli daerah (PAD), dana alokasi umum (DAU) dan dana alokasi khusus (DAK) untuk alokasi anggaran di daerah diukur dengan belanja tidak langsung dan belanja langsung. Sampel populasi dalam penelitian ini adalah 38 kabupaten di Jawa Timur pada tahun 2010 sampai 2012. Penelitian ini menggunakan data sekunder dalam bentuk Anggaran Pernyataan Pendapatan dan Belanja (APBD) Kabupaten. Sampling metode menggunakan metode sensus dengan mengambil seluruh populasi. alat penelitian yang digunakan adalah regresi linier berganda. Hasil penelitian ini menunjukkan bahwa PAD, DAU, DAK memiliki dampak positif dan signifikan terhadap belanja tidak langsung, jika dilihat lebih jauh, tingkat ketergantungan belanja tidak langsung lebih dominan dibandingkan dengan DAU dan DAK sedangkan PAD, DAU memiliki positif dan dampak yang signifikan terhadap belanja langsung. DAK perpengaruh dampak positif dan signifikan terhadap belanja langsung, tingkat ketergantungan belanja langsung lebih dominan terhadap PAD dibandingkan dengan DAU dan DAK.

*Email Korespondensi: 'diah_ekaningtias@yahoo.com 


\section{Pendahuluan}

Perkembangan daerah di Indonesia semakin pesat, seiring dengan adanya era baru dalam pelaksanaan otonomi daerah dan disentralisasi fiscal (Setiawan, 2010). UU Nomor 22 Tahun 1999 tentang Pemerintah Daerah yang kemudian direvisi dengan UU Nomor 32 Tahun 2004, mengamanatkan bahwa daerah diberi kewenangan yang luas untuk mengurus rumah tangganya sendiri dengan sedikit mungkin campur tangan pemerintah pusat. Pemerintah daerah mempunyai hak dan kewenangan yang luas untuk menggunakan sumber-sumber keuangan yang dimilikinya sesuai dengan kebutuhan dan aspirasi masyarakat yang berkembang di daerah. Menghadapi kondisi otonomi daerah Pemerintah Kabupaten/Kota harus memiliki kesiapan dan kemantapan sumber-sumber dana bagi pembiayaan pembangunan yang mutlak diperlukan untuk mewujudkan Pemerintah Kabupaten/Kota menjadi daerah yang mandiri dari ketergantungan pemerintah pusat.

Pembiayaan penyelenggaran pemerintahan berdasarkan asas desentralisasi di lakukan atas beban APBD. Penyelenggaran pemerintahan dan pelayanan kepada masyarakat berdasarkan asas desentralisasi, kepada daerah diberi kewenangan untuk memungut pajak/retribusi dan mengelola Sumber Daya Alam. Sumber dana bagi daerah terdiri dari Pendapatan Asli Daerah (PAD), Dana Perimbangan dan Pinjaman Daerah, Dekonsentrasi dan Tugas Pembantuan (Halim, 2002 : 64-65). Transfer merupakan konsekuensi dari tidak meratanya kemampuan keuangan dan ekonomi daerah. Tujuan dari transfer ini adalah untuk mengurangi kesenjangan fiskal antar pemerintahan dan menjamin tercapainya standar pelayanan publik.

Beberapa tahun berjalan, proporsi DAU terhadap penerimaan daerah masih yang tertinggi dibanding dengan penerimaan daerah yang lain, termasuk PAD. Hal ini menunjukkan masih tingginya ketergantungan pemerintah daerah terhadap pasokan dana dari pemerintah pusat, dalam jangka panjang ketergantungan semacam ini harus menjadi semakin kecil.
Berbagai investasi yang dilakukan pemerintah daerah diharapkan memberikan hasil positif yang tercermin dalam peningkatan PAD (Adi, 2006). Belanja daerah merupakan pengalokasian dana yang harus dilakukan secara efektif dan efisien, dimana belanja daerah dapat menjadi tolak ukur keberhasilan pelaksanaan kewenangan daerah.

Penelitian ini merupakan pe-ngembangan dari penelitian yang dilakukan oleh Maimunah dan Akbar (2008). Pengaruh DAU dan PAD terhadap Belanja daerah daerah penda Kabupaten/Kota di pulau Sumatra pada tahun 2004. Hal ini yang berbeda peneliti ingin mengetahui bagaimana pengaruh PAD, DAU dan DAK berpengaruh terhadap Belanja Daerah yang di ukur dengan Belanja Tidak langsung dan belanja Langsung pada Kabupaten/Kota di Jawa Timur.

Tujuan Penelitian ini adalah untuk memberikan bukti empiris pada pengaruh PAD,DAU \& DAK terhadap belanja daerah pada Kabupaten/Kota di Jawa Timur tahun 2010-2012. Manfaat yang diharapkan penelitian ini adalah: (1) Bagi Pemerintah, memberikan masukan kepada pemerintah daerah pusat dengan pendapatan asli daerah, dana alokasi umum, dana alokasi khusus dan belanja daerah, secara proporsional yang disajikan secara transparan sehingga dapat terwujud good governance. (2) Bagi Masyarakat, Penelitian ini di harapkan Sebagai tambahan khasanah bahan referensi dan bahan masukan bagi penelitian selanjutnya, yang berhubungan dengan masalah Akuntansi Sektor Publik yang ada.

\section{Telaah Teori dan Pengembangan Hipotesis}

\section{Teori fiscal federalism}

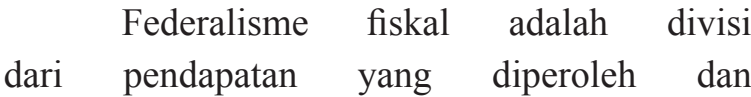
pertanggungjawaban pengeluaran dana di antara tingkatan pemerintah yang berbeda. Bentuk pemerintahan federalisme fiskal adalah struktur dari tingkatan pemerintah yang masing-masing tingkatan mempunyai sumber dari pendapatan dan mempunyai tanggung jawab. Federalisme fiskal adalah studi hubungan keuangan antar tingkatan pemerintah dimana sistem ini menggunakan 
program pemerintah yang meletakkan pada tingkat pemerintah yang berbeda. Berawal dari sebuah prinsip yang dapat diterapkan untuk semua negara yang berusaha mengaplikasikan desentralisasi fiscal, jadi federalisme fiskal merupakan perangkat prinsip pedoman untuk rancangan keuangan tingkat nasional dan subnasional pemerintah (Ferry, 2013).

\section{Anggaran Daerah}

Anggaran merupakan pernyataan mengenai estimasi kinerja yang hendak dicapai selama periode waktu tertentu yang dinyatakan dalam ukuran finansial, sedangkan penganggaran adalah proses atau metode untuk mempersiapkan suatu anggaran. Anggaran daerah merupakan salah satu alat yang memegang peranan penting dalam meningkatkan pelayanan publik dan didalamnya tercermin kebutuhan masyarakat dengan salah satu alat yang memegang peranan penting dalam meningkatkan pelayanan publik dan didalamnya tercermin kebutuhan masyarakat dengan memperhatikan potensi dan sumbersumber kekayaan daerah (Mardiasmo, 2002 : 61).

\section{Pendapatan Asli Daerah (PAD)}

Penerimaan Pendapatan Asli Daerah merupakan akumulasi dari Pos Penerimaan Pajak yang berisi Pajak Daerah dan Pos Retribusi Daerah, Pos Penerimaan Non Pajak yang berisi hasil perusahaan milik daerah, Pos Penerimaan Investasi serta Pengelolaan Sumber Daya Alam (Bastian, 2002). Pendapatan Asli Daerah (PAD) merupakan semua penerimaan daerah yang berasal dari sumber ekonomi asli daerah (Halim, $2002: 64)$.

\section{Dana Alokasi Umum}

Dana Alokasi Umum adalah dana yang bersumber dari pendapatan APBN yang dialokasikan dengan tujuan pemerataan kemampuan keuangan antar daerah untuk mendanai kebutuhan daerah dalam pelaksanaan desentralisasi Halim (2002 : 65). Pembagian dana untuk daerahmelalui bagi hasil berdasarkan daerah penghasil cenderung menimbulkan ketimpangan antar daerah dengan mempertimbangkan kebutuhan dan potensi daerah. Alokasi Dana Alokasi Umum bagi daerah yang potensi fiskalnya besar namun kebutuhan fiskalnya kecil akan memperoleh alokasi Dana Alokasi Umum yang relatif kecil.

\section{Dana Alokasi Khusus}

Berdasarkan Undang-undang No. 33 Tahun 2004, Dana Alokasi Khusus merupakan dana yang bersumber dari APBN yang dialokasikan kepada daerah tertentu dengan tujuan untuk membantu mendanai kegiatan khusus yang merupakan urusan daerah dan sesuai dengan prioritas nasional. Pemanfaatan DAK diarahkan pada kegiatan investasi pembangunan, pengadaan, peningkatan, dan perbaikan sarana dan prasarana fisik dengan umur ekonomis yang panjang, termasuk pengadaan sarana fisik penunjang.

\section{Alokasi Belanja Daerah}

Belanja daerah adalah semua pengeluaran Pemerintah Daerah pada suatu periode Anggaran. Anggaran Pendapatan dan Belanja Daerah terdiri daritigakomponenutama, yaitu unsurpenerimaan, belanja rutin dan belanja pembangunan. Ketiga komponen itu meskipun disusun hampir secara bersamaan, akan tetapi proses penyusunannya berada di lembaga yang berbeda (Halim, 2002 : 68).

Belanja daerah menurut kelompok belanja terdiri dari :

1. Belanja Tidak Langsung merupakan belanja yang dianggarkan tidak terkait secara langsung dengan pelaksanaan program dan kegiatan.

2. Belanja Langsung merupakan belanja yang dianggarkan terkait secara langsung dengan pelaksanaan program dan kegiatan.

\section{Pengaruh Pendapatan Asli Daerah (PAD terhadap Alokasi Belanja Daerah (ABD)}

Studi tentang pengaruh pendapatan daerah (local own resources revenue) terhadap pengeluaran daerah sudah banyak dilakukan, sebagai contoh penelitian yang pernah dilakukan oleh Bambang Prakosa (2004), Syukriy \& Halim (2003) menyatakan pendapatan (terutama 
pajak) akan mempegaruhi Anggaran Belanja Pemerintah Daerah dikenal dengan nama tax spend hyphotesis. Dalam hal ini pengeluaran Pemerintah Daerah akan disesuaikan dengan perubahan dalam penerimaan Pemerintah Daerah atau perubahan pendapatan terjadi sebelum perubahan pengeluaran. Belanja daerah adalah semua pengeluaran Pemerintah Daerah pada suatu periode anggaran (Halim, 2002 : 68). Alokasi belanja daerah terdiri dari belanja tidak langsung dan belanja langsung.

\section{Pengaruh Dana Alokasi Umum (DAU) terhadap Alokasi Belanja Daerah (ABD)}

Halim (2002 : 65) Dana Alokasi Umum (DAU) adalah dana yang berasal dari APBN yang dialokasikan dengan tujuan pemerataan keuangan antar daerah untuk mebiayai kebutuhan pengeluarannya di dalam pelaksanaan desentralisasi. Dana Alokasi Umum berpengaruh terhadap alokasi belanja tidak langsung yang dialokasikan untuk membiayai belanja pegawai berupa gaji dan tunjangan, belanja hibah, belanja bantuan sosial, belanja bagi hasil kepada Kabupaten/Kota dan Pemerintah Desa, belanja bantuan Keuangan kepada Kabupaten/Kota dan Pemerintah Desa, belanja tidak tersangka. Setiap tahun terjadi peningkatan belanja tidak langsung disebabkan oleh kebijakan Pemerintah Pusat yang terus menambah jumlah PNS, serta kenaikan gaji PNS. Dengan demikian Dana Alokasi Umum (DAU) tidak terlalu segnifikan, jika dibandingkan dengan kenaikan gaji pegawai tersebut. Namun didorong kewajiban untuk mengalokasikan belanja hibah sebagai komponen belanja tidak langsung. Sehingga DAU memiliki pengaruh terhadap belanja tidak langsung (Rahmawati, 2010).

\section{Pengaruh Dana Alokasi Khusus (DAK) terhadap Alokasi Belanja Daerah (ABD)}

Dana alokasi khusus adalah dana yang berasal dari APBD yang dialokasikan kepada daerah untuk membantu membiayai kebutuhan tertentu. Berdasarkan pasal 19 ayat 1 PP No. 104 Tahun 2000 tentang dana perimbangan, disebutkan bahwa dana alokasi dapat dialokasikan dari APBD kepada daerah tertentu untuk membantu membiayai kebutuhan khusus, dengan memperhatikan tersedianya dana dalam APBD (Halim, 2002 : 65). Alokasi Belanja Daerah terdiri dari belanja tidak langsung dan belanja langsung. Belanja tidak langsung merupakan belanja yang tidak memiliki keterkaitan secara langsung dengan pelaksanaan program dan kegiatan, terdiri dari belanja pegawai, belanja bunga, subsidi, hibah, bantuan sosial, belanja bagi hasil, bantuan keuangan dan belanja tidak terduga. Belanja langsung merupakan belanja yang memiliki keterkaitan secara langsung dengan program dan kegiatan yang meliputi belanja pegawai, belanja barang dan jasa serta belanja modal. Hipotesis dalam penelitian ini dapat dirumuskan sebagai berikut :

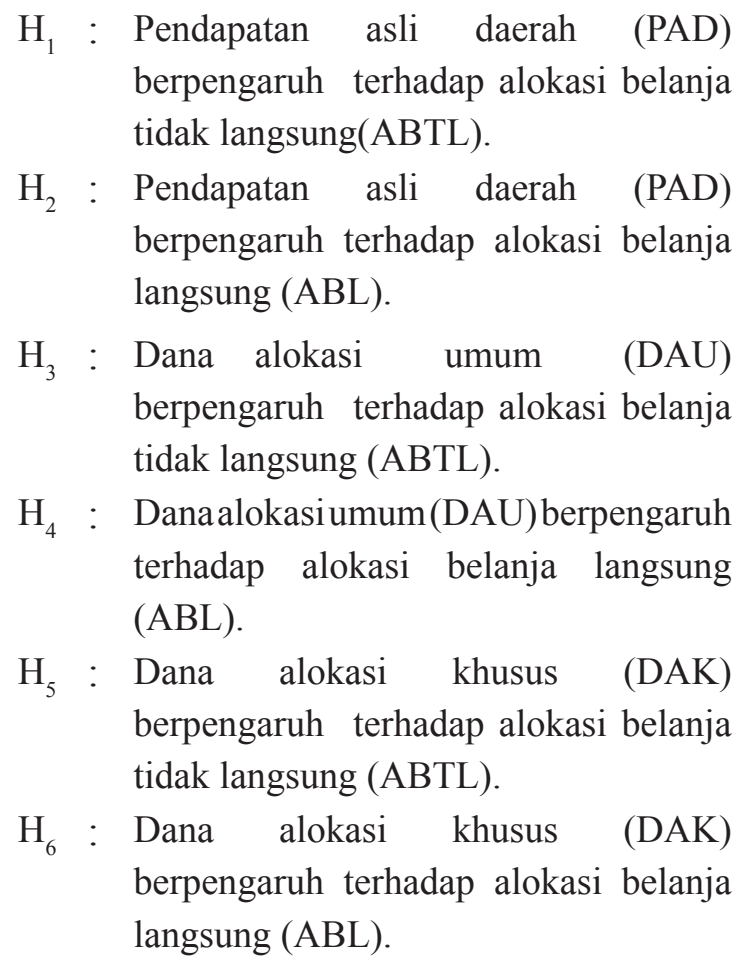

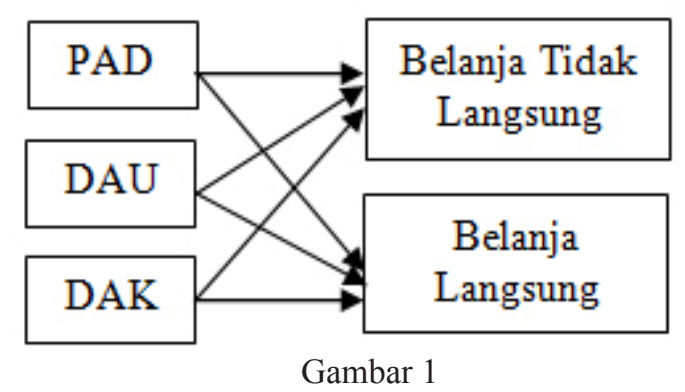

Kerangka Pemikiran 


\section{Metode}

Penelitian ini merupakan penelitian kuantitatif yaitu penelitian dengan pengujian teori-teori melalui pengukuran variabel-variabel penelitian dengan angka dan melakukan analisis data dengan prosedur statistik yang bertujuan untuk menguji hipotesis. Penelitian ini merupakan penelitian arsip berupa fakta yang tertulis (dokumen) atau berupa arsip. Proses pengumpulan datanya berupa dokumen atau arsip yang dapat dikerjakan sendiri oleh peneliti atau berupa publikasi data yang dikerjakan oleh orang lain (Indrianto dan Supomo, 1997 : 30).

Variabel yang akan diuji dalam penelitian ini terdiri dari variabel dependent (y) adalah belanja tidak langsung \& belanja langsung. Belanja Tidak Langsung merupakan belanja yang terkait secara langsung dengan pelaksanaan program dan kegiatan pemerintah. Rumus untuk menghitung alokasi belanja tidak langsung (ABTL) yaitu:

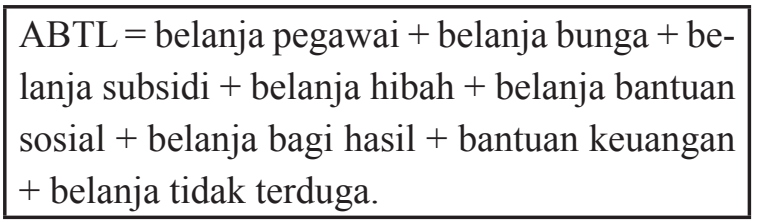

Belanja Langsung dengan program dan kegiatan pemerintah yang meliputi belanja pegawai, belanja barang dan jasa serta belanja modal. Rumus untuk menghitung alokasi belanja langsung (ABL) yaitu:

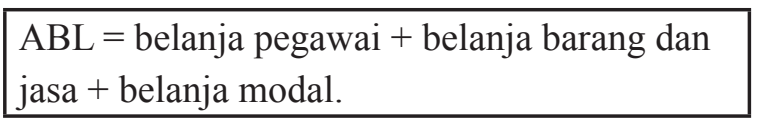

Variabel-variabel independen yang digunakan dalam penelitian ini meliputi:

\section{Pendapatan Asli Daerah (PAD)}

Pendapatan Asli Daerah

(PAD) merupakan semua penerimaan daerah yang berasal dari sumber ekonomi asli daerah. Rumus untuk menghitung Pendapatan Asli Daerah (PAD) yaitu:

PAD = Pajak daerah + Retribusi daerah + Hasil
pengelolaan kekayaan +daerah yang dipisah-
kan + Lain-lain PAD yang sah.

\section{Dana Alokasi Umum}

Dana Alokasi Umum (DAU) adalah transfer yang bersifat umum dari Pemerintah Pusat ke Pemerintah Daerah untuk mengatasi ketimpangan horizontal 'dengan tujuan utama pemerataan kemampuan keuangan antar daerah. Rumus untuk menghitung DAU adalah sebagai berikut:

DAU $=$ Celah Fiskal + Alokasi Dasar

Dimana,

Celah Fiskal $=$ Kebutuhan Fiskal - Kapasitas Fiskal

\section{Dana Alokasi Khusus}

Dana alokasi khusus adalah dana yang berasal dari APBD yang dialokasikan kepada daerah untuk membantu membiayai kebutuhan tertentu (Halim, 2002 : 65). Kebutuhan khusus adalah kebutuhan yang sulit diperkirakan dengan rumus alokasi umum, dan atau kebutuhan yang merupakan komitmen atau prioritas nasional.

Populasi dalam penelitian ini adalah seluruh Kabupaten/Kota Provinsi Jawa Timur terdiri dari 29 Kabupaten dan 9 Kota. Teknik pengambilan sampel pada penelitian mengambil seluruh populasi dengan beberapa kriteria sebagai berikut:

1. Kabupaten/kota menyampaikan Laporan Realisasi APBD tahunan kepada Dirjen Perimbangan Keuangan Pemerintah Daerah selama tahun 2010-2012.

2. Kabupaten/kota mencantumkan data-data mengenai PAD, DAU, DAK dan alokasi belanja daerah pada Laporan Realisasi APBD yang digunakan dalam penelitian ini.

\section{Hasil Penelitian dan Pembahasan}

Tujuan penelitian ini adalah untuk mengetahui dan menganalisis pengaruh PAD, DAU dan DAK terhadap Belanja Daerah yang diukur dengan belanja tidak langsung dan belanja langsung pada situs Dirjen Perimbangan Keuangan Pemerintah Daerah sebanyak 38 Kabupaten/Kota di Jawa Timur, dengan sampel 114 pada periode 2010 sampai 2012. Pengaruh 
pendapatan asli daerah (PAD), dana alokasi umum (DAU) dan dana alokasi khusus (DAK) untuk alokasi anggaran di daerah diukur dengan belanja tidak langsung dan belanja langsung diuji dengan menggunakan uji regresi berganda. Uji asumsi klasik digunakan untuk menguji kualitas data, terdiri dari uji normalitas, multikolinearitas, uji autokorelasi dan uji heteroskedastisitas. Uji normalitas data dilakukan untuk melihat apakah data yang dipakai dalam penelitian ini terdistribusi secara normal atau tidak (Ghozali, 2011:160). Di dalam penelitian ini untuk menguji normalitas adalah dengan Kolmogorov-Smirnov test. Dengan kriteria pengujian sebagai berikut : Nilai signifikansi $<0,05$. Data tidak terdistribusi normal. Nilai signifikansi $>0,05$. Data terdistribusi normal. Uji multikolonieritas Untuk mengetahui adanya multikolonieritas adalah dengan melihat Value Inflation Factor (VIF). Apabila nilai VIF > 10, maka disimpulkan terjadi multikolonieritas. Apabila nilai VIF $<10$, maka disimpulkan tidak terjadi multikolonieritas (Ghozali, 2011 : 105106). Uji autokorelasi bertujuan menguji apakah dalam model regresi berganda linier ada korelasi antara kesalahan penganggu pada periode $t$ dengan kesalahan penganggu pada periode t-1(sebelumnya). Penelitian ini menggunakan uji statistik Durbin Watson untuk mendeteksi ada atau tidaknya autokorelasi (Ghozali, 2011: 110-111). Bertujuan untuk menguji apakah model regresi terjadi ketidaksamaan varian dari residual satu pengamatan ke pengamatan lain. Untuk mengetahui adanya heteroskedastisitas dapat menggunakan grafik scatterplot. Namun, apabila tidak terjadi pola yang jelas, serta titiktitik menyebar di atas dan di bawah angka 0 pada sumbu Y, maka tidak terjadi heteroskedastisitas (Ghozali, 2011 : 139).

Hasil analisis statistik untuk uji asumsi klasik persamaan regresi pertama, one sampleKolmogrov-Smirnov Test 0,667 dan signifikan pada 0,765 . Nilai probabilitas signifikan ini di atas 0,05 , maka data residual terdistribusi normal. Hasil pengujian dengan memperhatiakn nilai VIF menunjukkan $<10$, artinya bahwa keseluruhan variabeltidakmengandungmultikolinearitas. Nilai DW sebesar 1,693, nilai ini akan kita bandingkan dengan nilai tabel dengan menggunakan nilai signifikansi 5\%, jumlah sampel 114 dan jumlah variabel independen $3(\mathrm{k}=3)$, maka nilai di dalam tabel durbin watson adalah nilai $\mathrm{dl}=1,641$ dan nilai $\mathrm{du}=1,7488$. Oleh karena nilai DW 1,693 lebih besar dari nilai (dl) 1,641 dan lebih kecil dari nilai (du) 1,7488, maka dapat disimpulkan bahwa tidak dapat diambil sebuah keputusan yang pasti untuk menerima dan menolak H0 (berada di daerah keragu-raguan. Hasil grafik scatterplots, terlihat bahwa titik-titik menyebar secara acak serta tersebar baik di atas maupun di bawah angka 0 pada sumbu Y. Hal ini dapat disimpulkan bahwa tidak terjadi heterokedastisitas pada model regresi.

Hasil analisis statistik untuk uji asumsi klasik persamaan kedua, one sample- KolmogrovSmirnov Test 1,636 dan signifikan pada 0,009. Nilai probabilitas signifikan ini di bawah 0,05 , maka data residual tidak terdistribusi normal. Salah satu cara untuk mengobati data yang tidak sesuai dengan asumsi klasik normalitas adalah dengan mentranformasi data tersebut menjadi persamaan semi log atau double log (Ghozali, 2011: 193). Setelah Double Log nilai Kolmogorov-Smirnov adalah 0,859 dan signifikan pada 0,451 . Nilai probabilitas signifikan ini di atas 0,05 , maka data residual terdistribusi normal. Hasil pengujian dengan memperhatiakn nilai VIF menunjukkan $<10$, artinya bahwa tidak ada multikoleniaritas antar variabel independen dalam model regresi. Nilai DW sebesar 1,241, nilai ini akan kita bandingkan dengan nilai tabel dengan menggunakan nilai signifikansi 5\%, jumlah sampel 114 dan jumlah variabel independen 3 $(\mathrm{k}=3)$, maka nilai di dalam tabel durbin watson adalah nilai $\mathrm{d} l=1,641$ dan nilai $\mathrm{du}=1,7488$. Oleh karena nilai DW 1,241 lebih kecil dari nilai (dl) 1,641 dan lebih kecil dari nilai (du) 1,7488, maka dapat disimpulkan bahwa terjadi autokorelasi. Hasil grafik secara acak serta tersebar baik di atas scatterplots, terlihat bahwa titik-titik menyebar maupun di bawah angka 0 pada sumbu Y. Hal ini dapat disimpulkan bahwa tidak terjadi hetero kedastisitas pada model regresi.

Analisis regresi berganda linier yang digunakan untuk melihat pengaruh pendapatan 
yaitu PAD, DAK dan DAU terhadap pengeluaran pemerintah yang berupa alokasi belanja daerah (belanja langsung dan belanja tidak langsung). Model analisis regresi variabel independen terhadap variabel dependen sekaran.

Ada dua persamaan regresi, persamaan regresi adalah:

$\mathbf{Y}_{1}=\alpha+\mathrm{b} 1 \mathrm{X}_{1}+\mathrm{b} 2 \mathrm{X}_{2}+\mathrm{b} 3 \mathrm{X}_{3}+\mathrm{e}_{1} \ldots$ persamaan (1)

dan

$\mathbf{Y}_{2}=\alpha+b 1 X_{1}+b 2 X_{2}+b 3 X_{3+} e_{2} \ldots$ persamaan (2)

dimana :

$\mathrm{Y}_{1} \quad=$ Belanja Tidak Langsung

$\mathrm{Y}_{2} \quad=$ Belanja Langsung

$\mathrm{X}_{1}=\mathrm{PAD}$

$\mathrm{X}_{2}=\mathrm{DAU}$

$\mathrm{X}_{3}=\mathrm{DAK}$

$\beta_{1} \beta_{2} \beta_{3}=$ koefisien regresi untuk masing-masing variabel X

Hasil uji regresi mencakup uji koefisien determinasi, Uji F, dan Uji t. Koefisien determinasi $\left(\mathrm{R}^{2}\right)$ digunakan untuk mengetahui sampai seberapa besar presentasi variasi variabel bebas pada model dapat dijelaskan oleh variabel terikat. Koefisien determinasi $\left(\mathrm{R}^{2}\right)$ dinyatakan dalam persentase yang nilainya berkisar antara $0<R^{2}<1$. Uji model penelitian ini dapat membuktikan apakah model dari penelitian fit atau tidak fit. Dalam uji ini dasar pengambilan keputusan dapat dilihat dari probabilitas signifikan uji model penelitian (Ghozali, 2011:98). Analisa regresi secara univariate dengan menggunakan metode t-test dengan taraf signifikansi 0.05 atau $5 \%$ untuk mengetahui pengaruh masing-masing variabel independen secara persial terhadap variabel dependen.

Belanja Tidak Langsung (BTL) memiliki nilai terendah, 169.903,5. Hasil penelitian BTL terendah di Jawa Timur diperoleh dari Kab. Mojokerto pada tahun 2010, sedangkan nilai BTL tertinggi 2.021.569,34. Hasil penelitian BTL tertinggi di Jawa Timur diperoleh dari kota Surabaya pada tahun 2011. Nilai rata-rata dari BTL 693.947,57 lebih besar dari pada nilai standar deviasi 315.344,75. Hal ini menunjukkan bahwa distribusi data cenderung normal. Belanja Langsung (BL) memiliki nilai terendah
134.439,78. Hasil penelitian menunjukkan BL terendah di Jawa Timur diperoleh dari Kab.Blitar pada tahun 2010, sedangkan nilai BL tertinggi 3.195.546,62. Hasil penelitian menunjukkan BL tertinggi di Jawa Timur diperoleh dari Kota Surabaya pada tahun 2012. Nilai rata-rata dari BL 426.277,66 lebih kecil dari nilai pada standar deviasi 465.024,47. Hal ini menunjukkan bahwa distribusi data cenderung tidak normal. Pendapatan Asli Daerah memiliki nilai terendah 25.217,31 Hasil penelitian menunjukkan PAD terendah di Jawa Timur diperoleh dari Kab.Pacitan pada tahun 2011. sedangkan nilai PAD tertinggi 2.353.324,92 Hasil penelitian menunjukkan Pendapatan Asli Daerah tertinggi di Jawa Timur diperoleh dari kota Surabaya pada tahun 2012. Nilai rata-rata dari PAD 132.240,37 lebih kecil dari pada nilai standar deviasi 307.249,57. Hal ini menunjukkan bahwa distribusi data cenderung tidak normal.

Dana Alokasi Umum memiliki nilai terendah223.964,25Hasilpenelitianmenunjukkan DAU terendah di Jawa Timur diperoleh dari Kota Blitarditahun2010, sedangkannilaiDAUtertinggi 1.281.612,87 Hasil penelitian menunjukkan DAU tertinggi di Jawa Timur diperoleh dari Kabupaten Malang di tahun 2012. Nilai rata-rata dari DAU 612.181,57 lebih besar dari pada nilai standar deviasi 214.512,32. Hal ini menunjukkan bahwa distribusi data cenderung normal. Dana Alokasi Khusus nilai terendah 424,10 Hasil penelitian menunjukkan DAK terendah di Jawa Timur diperoleh dari kota Kediri di tahun 2012, sedangkan nilai DAK tertinggi 157.273,64 Hasil penelitian menunjukkan DAK tertinggi di Jawa Timur diperoleh dari Kab. Jember di tahun 2012. dan nilai rata-rata 55.274,62 lebih besar dari pada nilai standar deviasi 26.046,18. Hal ini menunjukkan bahwa distribusi data cenderung normal.

Berdasarkan ouput SPSS nilai Angka $\mathrm{R}$ square untuk persamaan (1) adalah 0.940 (pengkuadratan dari koofisien korelasi atau $0.97 \times 0.97=0.940)$. R-square atau koofisien determinasi memiliki arti 93,9\% dari Belanja Tidak Langsung dapat dijelaskan oleh variabel PAD, DAU dan DAK. Untuk sisanya sebesar 
$6,1 \%$ dijelaskan oleh sebab-sebab yang lain. Tabel 4.14 menunjukkan hasil perhitungan statistik uji F sebesar 576,253 dengan probabilitas 0,000 . Karena probabilitas jauh lebih kecil dari 0,05 , maka model regresi ini bisa dipakai untuk memprediksi Belanja Tidak Langsung. Secara simultan, seluruh variabel independen PAD, DAU dan DAK berpengaruh secara signifikan terhadap variabel belanja langsung.

Belanja Tidak Langsung $=970,740+0,526$ PAD $+0,881 \mathrm{DAU}+1,522 \mathrm{DAK}+\mathrm{e}$

Hasil analisis regresi persamaan (1) menunjukkan bahwa variabel PAD berpengaruh positif terhadap Belanja Tidak Langsung Pada output regresi menunjukkan bahwa angka signifikansi untuk variabel PAD sebesar 0,000. Nilai ini lebih kecil dari tingkat signifikansi sebesar 0,05 sehingga dapat disimpulkan bahwa Pendaptan Asli Daerah secara individual mempengaruhi belanja tidak langsung, dan dapat disimpulkan hipotesis pertama diterima. Nilai signifikansi variabel $\mathrm{DAU}=0,000$ lebih kecil dari 0,05 , maka DAU berpengaruh positif dan signifikan terhadap BTL, dapat disimpulkan hipotesis ketiga diterima. variabel $\mathrm{DAK}=0,002$ lebih kecil dari 0,05 , maka DAK berpengaruh positif dan signifikan terhadap BTL, dapat disimpulkan hipotesis kelima diterima. Koefesien korelasi hubungan antar variabel Dependent (BTL) dengan Variabel bebas adalah PAD adalah 0,691, DAU adalah 0,842 dan DAK adalah 0,646 . Hal ini menunjukkan koofisien korelasi terbesar ada pada hubungan DAU dengan BTL, maka DAU jauh lebih berpengaruh terhadap BTL dibandingkan dengan PAD dan DAK.

Berdasarkan output SPSS untuk pengujian persamaan regresi (2) nilai Angka $\mathrm{R}$ square adalah 0.770 (pengkuadratan dari koofisien korelasi atau $0.878 \times 0.878=0.770)$. R-square atau koofisien determinasi memiliki arti $76,4 \%$ dari Belanja Tidak Langsung dapat dijelaskan oleh variabel LNPAD, LNDAU dan LNDAK. Untuk sisanya sebesar 23,6\% dijelaskan oleh sebab-sebab yang lain. Tabel 4.18 menunjukkan hasil perhitungan statistik uji F sebesar 123,096 dengan probabilitas 0,000 . Karena probabilitas jauh lebih kecil dari 0,05, maka model regresi ini bisa dipakai untuk memprediksi Ln Belanja Langsung. Secara simultan, seluruh variabel independen LnPAD, LnDAU dan LnDAK berpengaruh secara signifikan terhadap variabel Ln Belanja Langsung.

$\mathrm{LnBL}=2,583+0,528 \mathrm{LnPAD}+0,286 \mathrm{LnDAU}+$ $0,041 \mathrm{LnDAK}+\mathbf{e}$

Hasil analisis regresi menunjukkan bahwa variabel LNPAD berpengaruh positif terhadap LNBL Pada output regresi menunjukkan bahwa angka signifikansi untuk variabel LNPAD sebesar 0,000 . Nilai ini lebih kecil dari tingkat signifikansi sebesar 0,05 sehingga dapat disimpulkan bahwa LNPAD secara individual mempengaruhi LNBL, dan dapat disimpulkan hipotesis kedua diterima. variabel $\mathrm{LNDAU}=0,009$ lebih kecil dari 0,05, maka LNDAU berpengaruh positif dan signifikan terhadap LNBL, dapat disimpulkan hipotesis keempat diterima. variabel $\mathrm{LNDAK}=0,318$ lebih besar dari 0,05 , maka LNDAK tidak berpengaruh secara signifikan terhadap LNBL, dapat disimpulkan hipotesis keenam ditolak.

Hasil penelitian tersebut dapat membuktikan bahwa PAD berpengaruh positif terhadap belanja tidak langsung. Penulis hanya menemukan penelitian terdahulu oleh Rahmawati (2010) yang menyatakan bahwa Pendapatan Asli Daerah berpengaruh positif dan signifikan terhadap Belanja Tidak Langsung. Penelitian terdahulu lebih banyak membahas tentang PAD berpengaruh positif signifikan terhadap belanja daerah. Belanja tidak langsung merupakan bagian dari belanja daerah. Menurut penyataan Prakoso (2004) pendapatan daerah terutama pajak akan meningkatkan belanja daerah. Selain itu, Pendapatan Asli Daerah kabupaten/kota di Jawa Timur tebesar diperoleh dari pajak daerah dan retribusi daerah. Jika dilihat dari grafik 4.5 , terlihat bahwa PAD berpengaruh terhadap Belanja Tidak Langsung. Jika dana DAU tidak mencukupi untuk memenuhui kebutuhan belanja tidak langsung, maka dana PAD yang akan digunakan untuk memenuhi kebutuhan tersebut.

Hasil penelitian tersebut DAU berpengaruh positif terhadap belanja tidak langsung. 
Penulis belum menemukan peneliti terdahulu tentang pengaruh DAU terhadap belanja tidak langsung. Namun penulis hanya menemukan penelitian terdahulu oleh Anggraeni (2010) yang menyatakan bahwa terdapat pengaruh positif antara Dana Alokasi Umum terhadap belanja daerah. Hasil penelitian ini mendukung dari pada hasil penelitian Maemunah (2008) adalah DAU berpengaruh positif dan signifikan terhadap belanja daerah. Seperti yang di ketahui bahwa belanja tidak langsung merupakan bagian dari balanja daerah. DAU adalah dana yang bersumber dari pendapatan APBN yang dialokasikan dengan tujuan pemerataan kemampuan keuangan antar daerah untuk mendanai kebutuhan daerah dalam rangka pelaksanaan desentralisasi Halim (2002 : 65). Dalam UU No.33 tahun 2004 Pasal 27 menyatakan bahwa DAU dialokasikan atas dasar celah fiskal dan alokasi dasar. Celah fiskal adalah kebutuhan fiska dikurangi dengan kapasitas fiskal daerah. Alokasi dasar dihitung berdasarkan jumlah gaji Pegawai Negeri Sipil Daerah. Berdasarkan UU No.33 Tahun 2004 Pasal 27, alokasi DAU berhubungan langsung dengan belanja gaji pegawai. Belanja gaji pegawai mengambil porsi paling besar dalam kelompok Belanja Tidak Langsung

Hasil penelitian tersebut membuktikan bahwa DAK berpengaruh positif terhadap belanja tidak langsung. Penulis belum menemukan penelititerdahulu tentang pengaruhDAK terhadap belanja tidak langsung. Namun penulis hanya menemukan penelitian terdahulu oleh Nugraeni (2010) yang menyatakan bahwa terdapat pengaruh positif antara Dana Alokasi Khusus terhadap belanja daerah. Hasil penelitian ini mendukung dari pada hasil penelitian Situngkir (2009) adalah DAK berpengaruh positif dan signifikan terhadap belanja daerah. Seperti yang di ketahui bahwa belanja tidak langsung merupakan bagian dari balanja daerah. DAK merupakan alokasi pembiayaan daerah yang berasal dari APBN dan dialokasikan ke daerah kabupaten/kota untuk membiayai kebutuhan tertentu yang sifatnya khusus, tergantung tersedianya dana dalam APBN (Halim, 2002 : 65). Kebutuhan khusus adalah kebutuhan yang sulit diperkirakan dengan rumus alokasi umum, dan atau kebutuhan yang merupakan komitmen atau prioritas nasional. Beberapa komponen belanja tidak langsung adalah : bantuan keuangan yang dianggarkan untuk kepada kabupaten/kota dalam rangka peningkatan kemampuan keuangan, serta belanja tidak terduga untuk penanggulangan bencana alam dan bencana sosial. Jika dilihat dari sasaran penerimaan DAK berdasarkan kriteria teknis dan kriteria khusus, maka komponen belanja tidak langsung ini sesuai dengan sasaran DAK. Oleh karena itu, dapat disimpulkan bahwa DAK berpengaruh positif terhadap Belanja Tidak Langsung.

Hasil penelitian ini membuktikan bahwa PAD berpengaruh positif terhadap belanja langsung. Hasil penelitian ini sesuai dengan hasil penelitian yang dilakukan oleh Rahmawati (2010), yang menyatakan secara persial PAD berpengaruh signifikan terhadap belanja langsung. Tuasikal (2008), yang menemukan bahwa secara parsial PAD berpengaruh signifikan terhadap belanja modal, dengan pemahaman bahwa apabila belanja modal menurun maka dapat dipastikan bahwa belanja langsung juga akan menurun karena belanja modal merupakan bagian dari pada belanja langsung. Berdasarkan hasil uji korelasi pada tabel 4.20, maka PAD jauh lebih berpengaruh terhadap Belanja Langsung dibandingkan dengan DAU dan DAK. Hal ini wajar dikarenakan DAU lebih banyak digunakan untuk membiayai belanja tidak langsung oleh pemerintah kabupaten/kota di Jawa Timur.

DAU berpengaruh positif terhadap belanja langsung. Hasil penelitian ini sesuai dengan hasil penelitian yang dilakukan oleh Try Indraningrum (2011), yang menemukan bahwa secara persial DAU mempunyai pengaruh positif dan signifikan terhadap belanja langsung. Praditha (2012), yang menemukan bahwa secara parsial DAU mempunyai pengaruh positif dan signifikan terhadap belanja modal, dengan pemahaman bahwa apabila

belanja modal menurun maka dapat dipastikan bahwa belanja langsung juga akan menurun karena belanja modal merupakan bagian dari pada belanja langsung. Pernyataan 
Halim (2002 : 65) menyatakan bahwa Dana Alokasi Umum merupakan transfer yang besifat umum dari Pemerintah Pusat kepada Pemerintah Daerah untuk mengatasi ketimpangan horizontal yang bertujuan utama pemerataan kemampuan keuangan antar daerah. Beberapa daerah dengan PAD yang rendah, masih sangat bergantung dengan DAU baik untuk belanja langsung maupun belanja tidak langsung.

DAK tidak berpengaruh positif terhadap belanja tidak langsung. Dana alokasi khusus dipakai untuk menutup kesenjangan pelayanan publik antar daerah dengan prioritas pada bidang kegiatan pendidikan, kesehatan, infrastruktur, kelautan dan perikanan, pertanian, prasarana pemerintahan daerah. Permasalahan yang timbul adalah anggaran pengeluaran daerah yang tercermin dalam APBD untuk kegiatan yang didanai oleh dana alokasi khusus belum mencerminkan kebutuhan sesungguhnya dan cenderung tidak efisien (Suratno, 2011).

Hasil penelitian ini berlawanan dengan hasil penelitian yang dilakukan oleh Nugraeni (2011), Tuasikal (2008), dan Wandira (2013). Sumber-sumber pendapatan daerah dominan diperolehdan dipergunakansepertipendapatanasli daerah, DAU untuk membiayai penyelenggaran urusan pemerintah daerah dalam bentuk realisasi belanja langsung. Berdasarkan penlitian ini dapat dikemukakan bahwa porsi DAK terlalu kecil, dan cenderung digunakan untuk memenuhi kebutuhan khusus dalam belanja tidak langsung, sehinga DAK hanya berpengaruh terhadap belanja tidak langsung tetapi tidak berpengaruh terhadap belanja langsung.

\section{Simpulan, Keterbatasan dan Implikasi Hasil Penelitian}

Penelitian ini bertujuan untuk menguji apakah terdapat pengaruh yang signifikan antara variabel pendapatan asli daerah (PAD), dana alokasi umum(DAU), dana alokasi khusus (DAK) terhadap belanja daerah yang di ukur dengan belanja tidak langsung dan belanja langsung, pada Kabupaten/Kota di Jawa Timur. Sampel penelitian ini di ambil dari situs Dirjen Perimbangan
Keuangan Pemerintah Daerah sebanyak 38 Kabupaten/Kota di Jawa Timur. Penelitian ini dilakukan pada tahun 2010-2012 dengan data penelitian sebanyak 114 Kabupaten/Kota. Hasil pengujian hipotesis dengan menggunakan analisis regresi berganda dengan tiga variabel independen yaitu pendapatan asli daerah (PAD), dana alokasi umum (DAU) dan dana alokasi khusus (DAK), dua variabel dependen yaitu alokasi belanja tidak langsung dan alokasi belanja langsung pada Kabupaten/Kota Jawa Timur periode 2010-2012 menunjukkan bahwa:

Hipotesis pertama Pendapatan Asli Daerah (PAD) berpengaruh positif dan signifikan terhadap Belanja Tidak Langsung (BTL). Pendapatan Asli Daerah kabupaten/kota di Jawa Timur terbesar diperoleh dari pajak daerah dan retribusi daerah. Hal ini, membuktikan bahwa pemerintah daerah Kabupaten/Kota di Jawa Timur tahun 2010 samapai dengan 2012 mampu mengupayakan sumber-sumber pendapatan yang dimiliki oleh kegiatan pemerintah sehingga mampu memberikan pelayanan yang terbaik untuk meningkatkan kesejahteraan masyarakat sekitarnya. Oleh karena itu, Pemerintah Daerah yang memiliki PAD tinggi maka pengeluaran untuk alokasi belanja tidak langsung juga semakin tinggi.

Hipotesis kedua Pendapatan Asli Daerah (PAD) berpengaruh positif dan signifikan terhadap Belanja Langsung (BL). Hal ini, membuktikan Kemandirian daerah dapat diukur dengan tingginya jumlah penerimaan Pendapatan Asli Daerah yang didapat oleh setiap daerah, semakin tinggi jumlah Pendapatan Asli Daerah maka semakin tinggi pula tingkat kemandirian daerah dalam menggali sumber daya daerah, sehingga dapat meningkatkan pertumbuhan ekonomi daerah melalui pengalokasian belanja langsung.

Hipotesis ketiga dana Alokasi Umum (DAU) berpengaruh positif dan signifikan terhadap Belanja Tidak Langsung (BTL). Oleh karena itu pemerintah pusat memberikan dana transfer kepada pemerintah daerah dengan tujuan pemerataan kemampuan keuangan daerah. Hal ini menujukkan bahwa Pemerintah Daerah yang 
memiliki DAU tinggi memiliki ketergantungan yang tinggi terhadap pemerintah pusat, Sehingga pemerintah pusat memberikan Dana Alokasi Umum yang diharapkan dapat meningkatkan pengalokasian belanja tidak langsung disetiap daerah Kabupaten/Kota di Jawa Timur.

Hipotesis keempat dana Alokasi Umum (DAU) berpengaruh positif dan signifikan terhadap Belanja Langsung (BL). Hal ini berarti dana alokasi umum (DAU) dengan tujuan pemerataan keuangan antar daerah untuk membiayai kebutuhan pengeluaran didalam pelaksaan desentralisasi. Kabupaten/Kota di Jawa timur semakin besar pula tingkat penerimaan dana alokasi umum (DAU) maka semakin besar juga tingkat ketergantungan daerah tersebut. Pemberian bantuan ini diupayakan untuk meningkatkan belanja langsung di setiap daerah sehingga dapat meningkatkan pelayanan publik untuk masyarakat.

Hipotesis kelima dana Alokasi Khusus (DAK) berpengaruh positif dan signifikan terhadap Belanja tidak Langsung (BTL). Hal ini berarti penerimaan dana alokasi khusus yang diterima dari pemerintah pusat oleh Kabupaten/ Kota di Jawa Timur

relatif besar, sehingga pemerintah pusat memberikan dana bantuan dana alokasi khusus (DAK) yang diharapkan dapat meningkatkan pengalokasian belanja tidak langsung seperti bantuan keuangan yang dianggarkan kepada Kabupaten/Kota di Jawa Timur untuk meningkatkan kemampuan keuangan, serta belanja tidak terduga untuk pengeluran bencana alam dan bencana sosial. Sehingga pemerintah daerah tetap dapat meningkatkan pelayanan publik untuk masyarakat.

Hipotesis keenam dana Alokasi Khusus (DAK) berpengaruh positif dan tidak signifikan terhadap Belanja Langsung (BL). Hal in berarti dana alokasi khusus (DAK) dipakai untuk menutup kesenjangan pelayanan publik antar daerah dengan prioritas pada bidang kegiatan pendidikan, kesehatan, infrastruktur, kelautan, perikanan dan pertanian, prasarana pemerintah daerah.permasalahanyang timbuladalahanggaran pengeluaran daerah tercermin dalam anggaran pendapatan belanja daerah (APBD) untuk kegiatan yang didanai oleh dana alokasi khusus belum mencerminkan kebutuhan sesungguhnya dan cenderung tidak efesien. Sehinnga hipotesis keenam dana alokasi khusus tidak berpengaruh signifikan terhadap belanja langsung.

Keterbatasan yang terdapat pada penelitian ini yaitu.periode penelitian ini hanya tiga tahun (Tahun 2010-2012) sehingga masih kurang dalam melakukan generalisasi. Selain itu variabel bebas yang digunakan hanya dari aspek keuangan sehingga kurang lengkap. Studi ini tidak menganalisis lebih jauh efektifitas dan efisiensi penggunaan anggaran (misalnya tidak mempertimbangkan jumlah, struktur usia, dan tingkat pendidikan pegawai dan penduduk).

Bagi penelitian selanjutnya perlu menambah, mengurangi atau mengganti variabelvariabel lain baik ukuran-ukuran atau jenis-jenis penerimaan Pemerintah Daerah lainnya, maupun variabel non-keuangan. Bagi peneliti` selanjutnya disarankan untuk memperbanyak sensus yang digunakan agar hasilnya lebih representatif terhadap populasi yang dipilih dan mengambil sempel selain kabupaten dan kota yang ada di Provinsi Jawa Timur. Pemerintah Daerah sebaiknya lebih mengoptimalkan potensi ekonomi lokalnya untuk menambah penerimaan daerah sehingga tercipta kemandirian daerah untuk membiayai pengeluaran-pengeluarannya. Hal ini akan memberikan dampak bahwa ketergantungan pada Pemerintah Pusat bisa dikurangi. Pemerintah daerah sebaiknya lebih mengoptimalkan belanja daerah karena semakin besar belanja daerah diharapkan kegiatan perekonomian daerah (terjadi ekspansi perekonomian). Saran ini disampaikan karena permasalahan yang dihadapi dalam belanja daerah adalah masih dominannya belanja tidak langsung di bandingkan belanja langsung dalam komposisi belanja daerah

\section{Daftar Rujukan}

Abdullah, Syukriy \& Abdul Halim, 2003, "Pengaruh Dana Alokasi Umum (DAU) dan Pendapatan Asli Daerah (PAD) terhadap Belanja Pemerintah Daerah: Studi Kasus Kabupaten/Kota di Jawa Tengah dan Bali”, 
Simposium Nasional Akuntansi VI, Surabaya, hal.1140-1159.

Setiawan, Anjar, 2011. Pengaruh Pendapatan Asli Daerah (PAD) dan Dana Alokasi Umum (DAU) Terhadap Belanja Daerah Studi Pada Provinsi Jawa Tengah. Skripsi Sarjana (Tidak dipublikasikan), Universitas Diponegoro Semarang.

Tuasikal, Askam, 2008., Pengaruh DAU,DAK,PAD dan PDRB terhadap Belanja Modal Pemerintah Daerah Kabupaten/Kota Indonesia. Jurnal Telaah \& Riset Akuntansi. Vol. 1, No. 2. Hal.142-155.

Wandira, GugusArbie,2013.PengaruhPAD,DAU, DAK, dan DBH Terhadap Pengalokasian Belanja Modal pada pemerintah provinsi se Indonesia. Accounting Analysis Journal. AAJ 1 (3) 2013.

Ferry,. 2013."Bagian V111 Federalisme”. Available online at: http://ferryfebub. lecture.ub.ac.id/files/2013/01/Bagian-VIII Federalisme.pdf._(diakses Maret 2013)

Ghozali, Imam. 2011. Aplikasi Analisis Multivariat Dengan Program SPSS. Edisi 5. Badan Penerbitan Universitas Diponegoro: Semarang.

Halim, Abdul. 2007. Akuntansi Sektor Publik: Akuntansi Keuangan Daerah. Edisi 3. Salemba 4 : Jakarta.

Halim, Abdul. 2002. Akuntansi Sektor Publik: Akuntansi Keuangan Daerah. Salemba 4 : Jakarta.

Mutiara, Maimunah dan Rusdi Akbar (2008). Flypaper Effect pada Dana Alokasi Umum (DAU) dan Pendapatan Asli Daerah (PAD) terhadap Belanja Daerah pada Kabupaten/ Kota di Pulau Sumatera. Jurnal Riset Akuntansi Indonesia. Vol. 1 I, No. 1, Januari 2008. Hal. 37-51.

Mardiasmo. 2002. Otonomi dan Manajemen keuangan daerah. Penerbit Andi: Yogyakarta.

Pratiwi, Novi. 2007. Pengaruh Dana Alokasi Umum (DAU) Dan Pendapatan Asli Daerah (PAD) Terhadap Prediksi Belanja Daerah Pada Kabupaten/Kota di Indonesia. Skripsi Sarjana (dipublikasikan). Fakultas Ekonomi
UII: Yogyakarta.

Praditha, Indah Ratna, 2012. Pengaruh

Pendapatan Asli Daerah Dan Dana Alokasi

Umum Terhadap Belanja Modal Di Provinsi

Jawa Timur. Universitas Negeri Surabaya.

Suratno. 2011. Analisis Faktor-Faktor Pendapatan

Dominan Dan Implikasinya Terhadap Anggaran Belanja Daerah. Fakultas Ekonomi Universitas Esa Unggul Jakarta. http://www. univpancasila.ac.id

Sukriy dan Halim Abdullah (c), "Pengaruh Dana Alokasi Umum (DAU) Dan Pendapatan Asli Daerah (PAD) terhadap Belanja Pemerintah Daerah":Studi Kasus Kabupaten/Kota Di Jawa dan Bali, Simposium Nasional Akuntansi VI:1140-1159, Surabaya 16-17 Oktober 2003.

Indraningrum, Try, 2011. "Pengaruh pendapatan asli daerah (PAD) dan dana alokasi umum (DAU) terhadap belanja langsung pada pemerintah daerah kabupaten/kota di provinsi jawa tengah". Skripsi sarjana (dipublikasikan). Fakultas Ekonomi UNDIP: Semarang. 